Int. J. Odontostomat.,

14(2):167-171, 2020.

\title{
Treatment of Naso-Orbito-Etmoidal Type III Fracture in Adolescents - Case Report
}

\author{
Tratamiento de la Fractura Naso-Orbito-Etmoidal \\ Tipo III en Adolescentes: Relato de un Caso
}

Rocha, J. L. S.; Cavalieri-Pereira, L.; Brancher, G. Q. B.; Altafin, L.; Cerezetti, L. \& Mirandola, C.

ROCHA, J. L. S.; CAVALIERI-PEREIRA, L.; BRANCHER G. Q. B.; ALTAFIN, L.; CEREZETTI, L. \& MIRANDOLA, C. Treatment

of naso-orbito-etmoidal Type III fracture in adolescents - Case report. Int. J. Odontostomat., 14(2):167-171, 2020.

\begin{abstract}
The naso-orbito-ethmoidal region is composed of delicate bones and when fractured may result in significant aesthetic-functional impairment. Diagnosis through clinical and imaging findings is extremely important for surgical planning. This study aims to report a case of type III fracture of the naso-orbito-ethmoidal region. Patient D.R.S., female, 13 years old, attended the emergency department of Hospital dos Fornecedores de Cana de Piracicaba (HFCP) - SP with complaint of pain in the fronto-nasal region and respiratory distress after trauma in face of baseball bat. Physical examination showed edema and short blunt injury in the region of the nasal dorsum and frontal region, bilateral periorbital hematoma, hyposphagma in right eye and traumatic telecanthus. When analyzing the computed tomography, it was observed fracture of the nasal bones, also affecting the medial wall of the orbit. The procedure was osteosynthesis of the fractures and reconstruction of the nasal dorsum. The fracture traces were exposed from coronal access, reduction of fractures and use of calvarial bone graft for nasal dorsum reconstruction. The fracture and the graft were fixed with plates of $1,6 \mathrm{~mm}$. Postoperative computed tomography analysis showed good graft positioning, but there was still a slight sinking of the left lateral wall of the nose. In a second moment another surgical intervention was done to reduce this wall and an internal containment device was installed. Currently the patient is in a state of observation and a follow-up period of 665 days. In cases of complex nasoorbito-ethmoidal fractures early diagnosis and treatment is essential to minimize sequelae and provide a better aesthetic and functional result.
\end{abstract}

KEY WORDS: internal fixation of fractures, reduction open, facial bones, facial injuries.

\section{INTRODUCTION}

The naso-death-ethmoidal region is composed of delicate bones that can easily fracture after medium or low impact trauma (Silva et al., 2014), it relates to the orbital, nasal, paranasal and frontal sinuses presenting a physiology associated with vision, smell and breathing (Soares et al., 2004).

The naso-orbito-etmoidal fracture (NOE) corresponds to 9 to $10 \%$ of the face fractures. It has a prevalence in male patientes with a age variation of 20- to 30-year-old, being rare in children (Silva et al.).

The correct diagnosis and treatment plan can prevent deformities such as traumatic telecanthus, defects in the nasal dorsum, reduced nasal permeability or dystopia (Herford et al., 2005).
They are classified in type I, II, III according to the amount of fragments adhered to the medial cantal ligament. Class I is represented by a single central fragment with the ligament adhered to it, class II has fragments comminuted but with the ligament still adhered, and class III presents comminution of the fragments and loss of adhesion of the medial cantal ligament (Markowitz et al., 1991).

In order to obtain a more precise diagnosis, CT is used because of the difficult clinical evaluation caused by edema, helping to define the extent of fracture and involvement of deep face structures (Soares et al.). The treatment of NOE fractures is aimed at restoring the patient's aesthetics and function, restoring the adequate architecture of the frontal, nasal bone, intercantal 
distance and maintenance of the lacrimal drainage system (Melo et al., 2015).

Although the basic concepts of osteosynthesis of NOE fractures are similar in adults and children, the latter still suffer unavoidable changes in the maxillofacial region, making it difficult to manage these fractures (Liau et al., 2011). This study aims to report a case of type III fracture of the naso-orbito-ethmoidal region in a teenage patient.

\section{CASE REPORT}
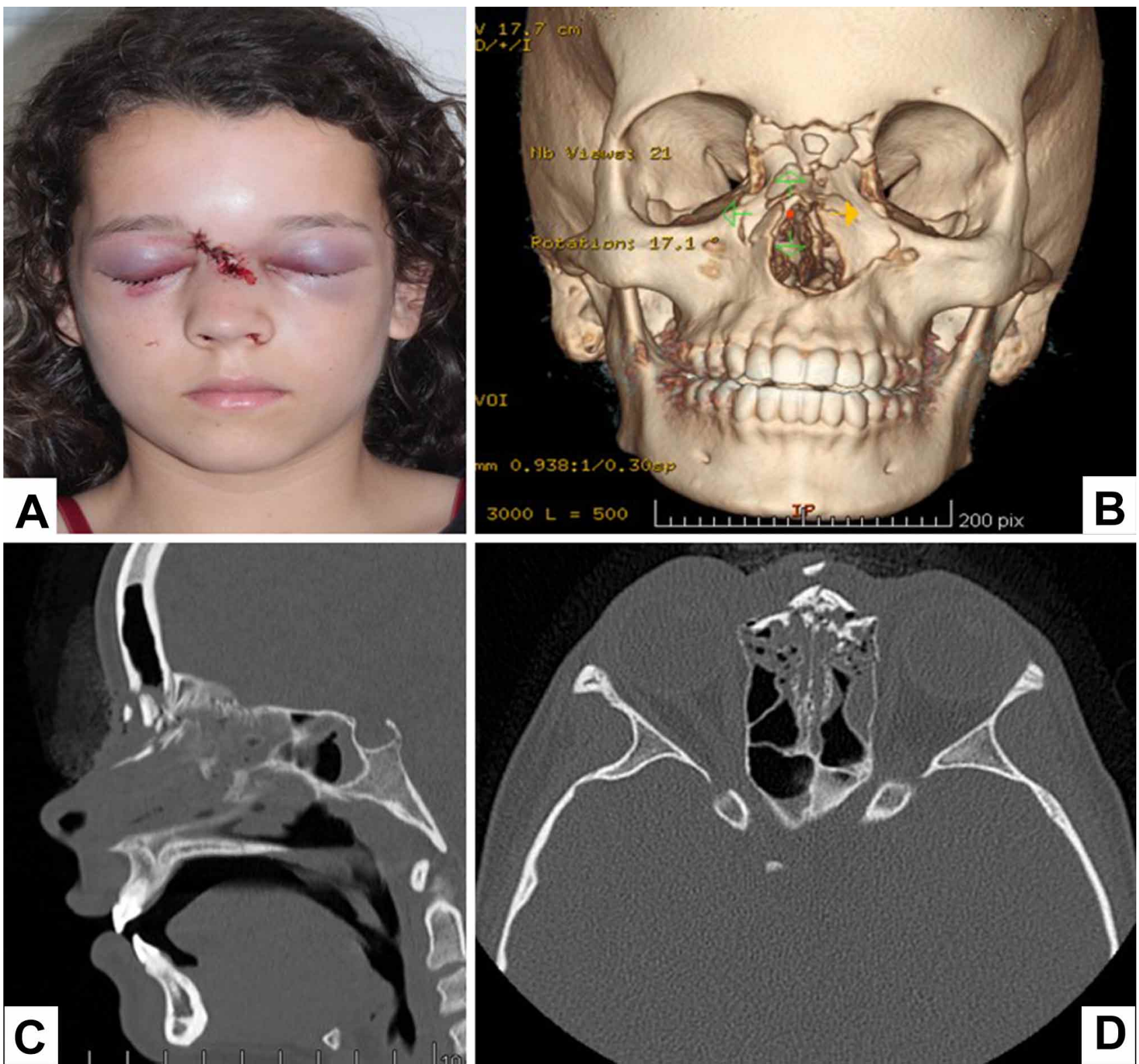

Fig. 1. Preoperative pictures. A. Patient frontal view. B. 3D reconstruction of the CT scan. C. Sagital view oh the CT scan. D. Axial view of the CT scan.
Patient DRS, white female, 13 years old, was referred to the Buco-Maxillofacial Surgery and Traumatology Service of the Hospital dos Fornecedores de Cana de Piracicaba (HFCP) - SP complaining about pain in the fronto-nasal region and respiratory distress after trauma in the face with baseball bat. In the medical history, the mother of the patient denied comorbidities, allergies and regular use of medicines. Physical exam showed edema and short blunt injury in the region of the nasal dorsum and frontal region, bilateral periorbital hematoma, hyposphagma in right eye and traumatic telecanthus. The patient denied double vision and presented the 
ROCHA, J. L. S.; CAVALIERI-PEREIRA, L.; BRANCHER G. Q. B.; ALTAFIN, L.; CEREZETTI, L. \& MIRANDOLA, C. Treatment of naso-orbito-etmoidal Type III fracture in adolescents Case report. Int. J. Odontostomat., 14(2):167-171, 2020.

extrinsic movements of the eyes preserved.

In frontal view of the patient (Fig. 1A), bilateral periorbital hematoma and edema and lacerations in the region of nasal dorsum was observed.

In a 3D reconstruction of the CT scan (Fig. 1B), fracture of the nasal bones and medial wall of orbit was noted.

In a sagital view of the CT scan (Fig. 1C), there is loss of nasal dorsum projection.

In a axial view of the CT scan (Fig. 1D), comminution of the NOE fracture was observed.

When analyzing the face CT a fracture of the nasal bones and the medial wall of the orbit was observed. After the clinical and imaging evaluation confirming a type III NOE fracture, the chosen approach for the treatment of the patient was fracture osteosynthesis and nasal dorsal reconstruction.
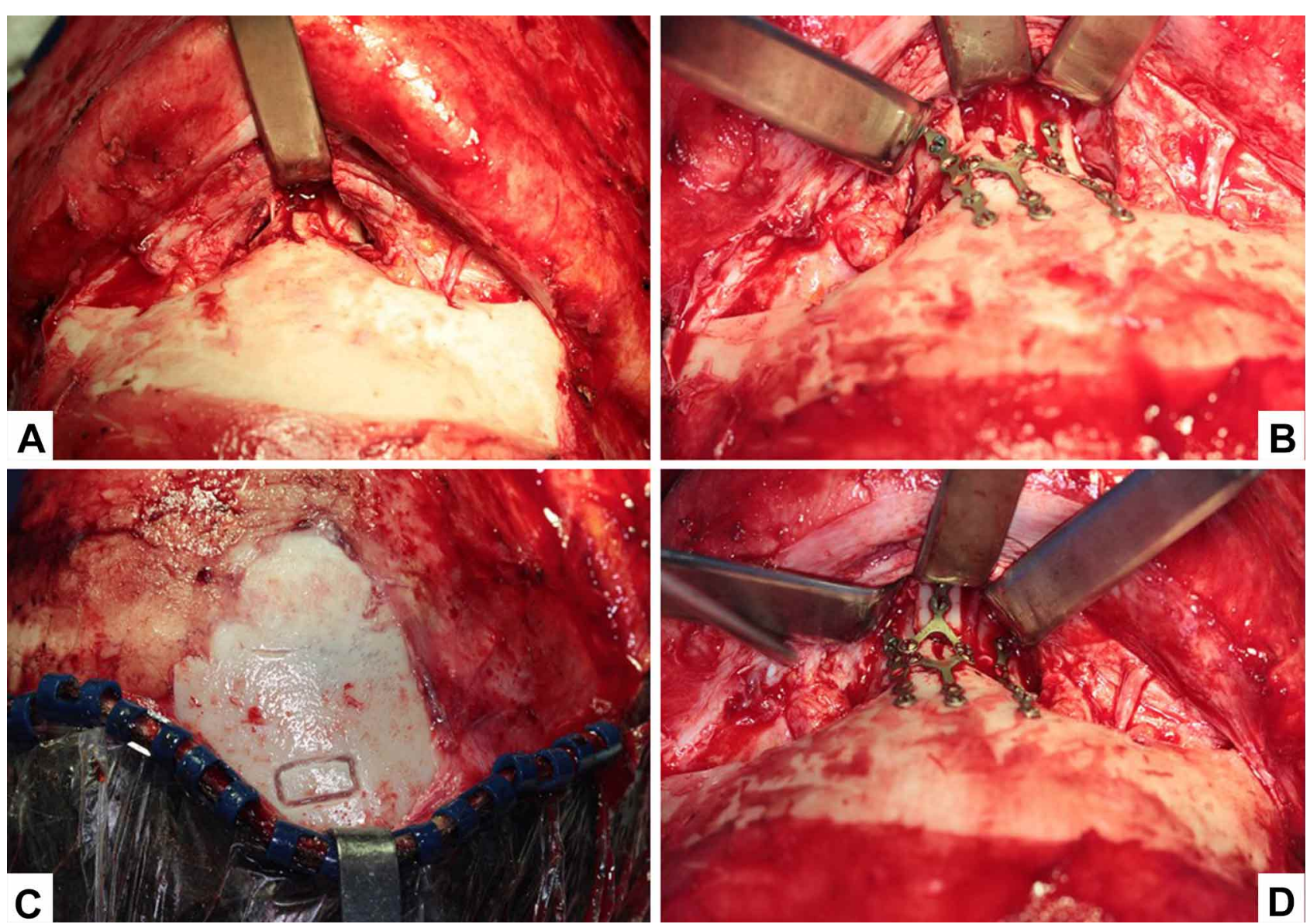

Fig. 2. Intraoperative photos. A. Nasoorbital ethmoid fracture. B. Fracture osteosynthesis. C. Calvarial bone graft. D. Nasal dorsum reconstruction.

The patient was submitted to the surgical procedure under general anesthesia. The exposure of the fracture was performed through the bicoronal access with the divulsion and incision of the subgaleal layer $4 \mathrm{~cm}$ above the supraorbital rim, then the pericranial was removed for the complete visualization of the fracture (Fig. 2A) The fracture of the nasal dorsum and medial wall of the orbit was then reduced, fixed with three plates of the system $1.6 \mathrm{~mm}$ (one in $\mathrm{Y}$ and two straight) (Fig. 2B).

In order to return the contour of the nasal dorsum, a reconstruction with bone of the region of the right posterior parietal was realized (Fig. 2C), the osteotomy was performed with a reciprocating saw and deepened with a 702 drill at $45^{\circ}$, a block of bone with a curved chisel was removed and fixed in a region of nasal dorsum with the Y-plate of the $1.6 \mathrm{~mm}$ system (Fig. 2D). For the treatment of traumatic telecanthus, transnasal cantopexy was performed, which consisted of the passage of a orthodontic $0,3 \mathrm{~mm}$ wire transfixing the medial canthal ligament and posterior to lachrymal 
sacs, the wires were fixed with two screws of the $1,5 \mathrm{~mm}$ system in the bilateral supraorbital region. Suture was performed by planes with 4-0 vicryl in pericranium and nylon 3-0 in the scalp, in addition to suturing of the short blunt nasal dorsal wound with vicryl 4-0 and nylon $6-0$. To support the lateral walls of the nose, nasal packing with glove fingers and gauze soaked in nebacetin, the nasal plug was fixed with 3-0 nylon and held for 2 days.

In the postoperative period of 26 days a slight inferiorization of the left lateral wall of the nose was observed, and a second surgical intervention was performed under general anesthesia to reduce and regulate the septum and lateral wall with a speculum. A internal containment device was installed, fixed with nylon 3-0, and maintained for 3 days.

Postoperative CT scanning showed a good fixation of the plaques and graft, providing a good aesthetic to the patient, which is maintained at the 665-day proservation where a good facial harmony can be observed, similar to the period before the trauma. The projection of the nasal dorsum is maintained, and the patient does not present double vision and maintains the extrinsic movements of the eyes, approaching normality.

\section{DISCUSSION}

In order to reconstruct the middle and upper third of the face, the treatment of NOE fractures should be correctly planned through clinical and imaging diagnosis as mentioned by Soares et al. Early intervention seeks to minimize possible complications and deformities caused by trauma, one of them being traumatic telecanthus and nasal dorsum sinking as presented by the patient in question.

The surgical access used was bicoronal, allowing a good visibility of the fracture and wide field for the correct reduction and fixation as described by Ellis 3rd (1993). Although it is a minimally detrimental access to aesthetics, the literature reports cases of complications such as alopecia and hypoesthesia, the patient, however, did not

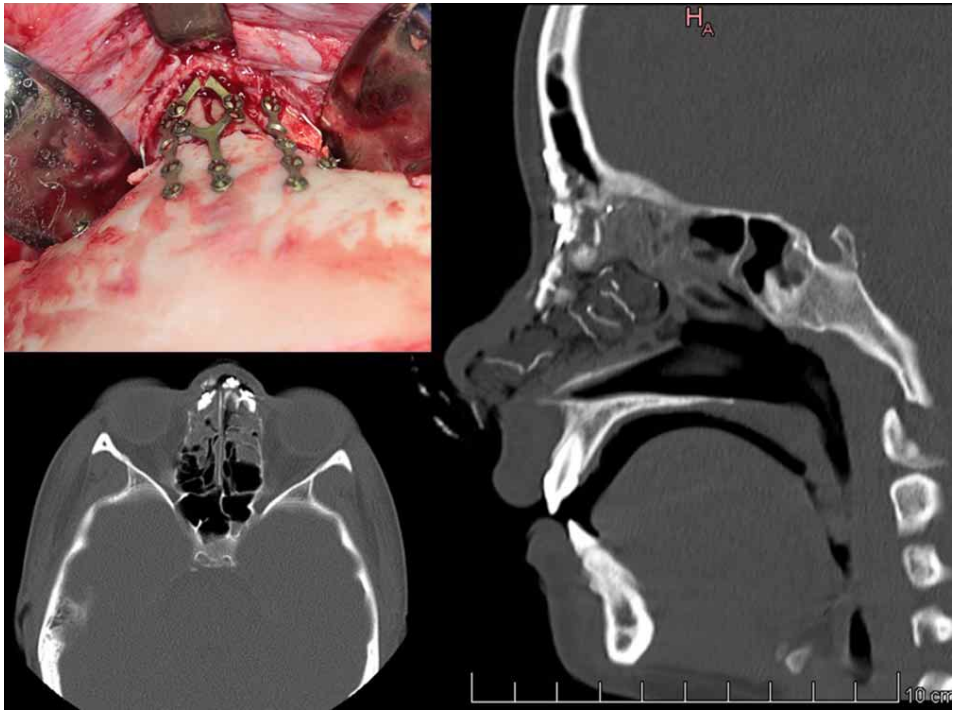

Fig. 3. A. Transnasal canthopexy. B. Axial view of the posoperative CT scan. C. Posoperative sagital view.
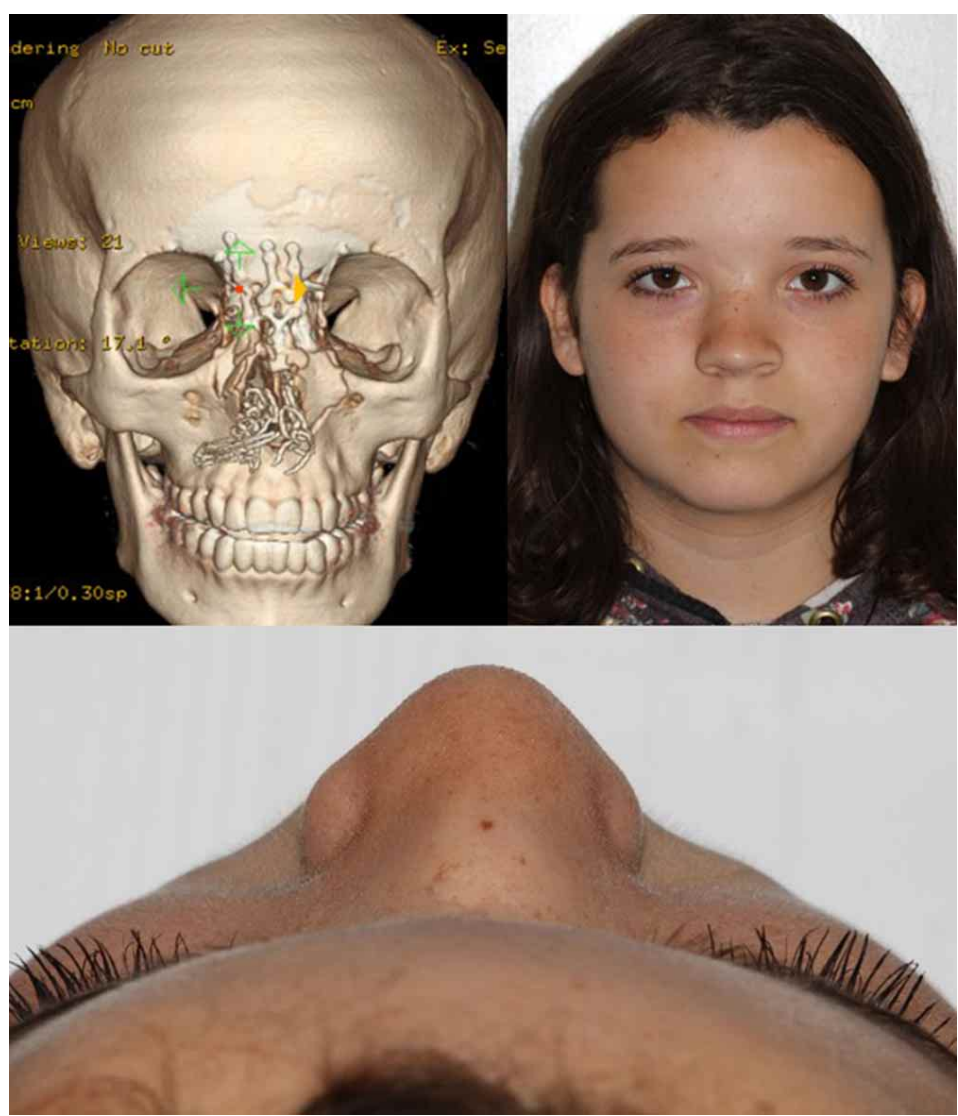

Fig. 4. Posoperative pictures A. Posoperative 3D reconstruction.C. B. Patiente frontal view. C. Patient axial view.

present them in the postoperative period, evidencing the good result of the access from the correct execution and knowledge of the surgical technique. 
ROCHA, J. L. S.; CAVALIERI-PEREIRA, L.; BRANCHER G. Q. B.; ALTAFIN, L.; CEREZETTI, L. \& MIRANDOLA, C. Treatment of naso-orbito-etmoidal Type III fracture in adolescents Case report. Int. J. Odontostomat., 14(2):167-171, 2020.

Through the reduction of the medial cantal ligament by cantopexy, it is aimed at the return of the adequate intercantal distance of the patient, obtaining a more satisfactory aesthetic result. According to Markowitz et al., only $3 \%$ of patients with this type of fracture had displacement of the medial canthal ligament, making their reinsertion one of the most important steps in preserving the intercantal distance.

The reconstruction of the nasal dorsum associated with the reduction of the nasal fracture promotes a better result regarding the projection of the nasal dorsum evidenced by the NOE type III fracture, as demonstrated by Heford; Ying \& Brown in 2005, together with the septum correction, provide a better respiratory and aesthetic function for the patient.

In the clinical case, a calvarial bone graft was used for the reconstruction, it presents a low reabsorption rate, providing a favorable long-term result in the support of the nasal dorsum. Presenting low morbidity, since the donor area is located in the same operative field as the area to be reconstructed, thus being a viable graft option for craniofacial reconstruction as described by Maves \& Matt (1986).

\section{CONCLUSION}

In cases of complex naso-orbito-occlusal fractures, early diagnosis and treatment are essential to minimize sequelae and provide a better aesthetic and functional results. The patient is under observation and does not present significant sequelae related to the trauma or the surgical procedure.

ROCHA, J. L. S.; CAVALIERI-PEREIRA, L.; BRANCHER G. Q. B.; ALTAFIN, L.; CEREZETTI, L. \& MIRANDOLA, C. Tratamiento de la fractura naso-orbito-etmoidal tipo III en adolescentes: Relato de un caso. Int. J. Odontostomat., 14(2):167-171, 2020.

RESUMEN: La región etmoidal nasoorbital está compuesta de huesos delicados y, cuando se fractura, puede provocar una lesión estética-funcional significativa. El diagnóstico mediante hallazgos clínicos y de imagen es de suma importancia para la planificación quirúrgica. El paciente D.R.S., mujer, 13 años, leucoderma, asistió al servicio de emergencia del Hospital de Proveedores de Caña de Azúcar de Piracicaba quejándose de dolor en la región frontal-nasal y dificultad para respirar después de un traumatismo en la cara con un palo. El examen físico reveló edema y lesión contundente en el dorso nasal y la región frontal, hematoma periorbitario bilateral, hiposfagma del ojo derecho y telecanto traumático. Al analizar la tomografía computarizada se observó fractura de los huesosnasales en libro abierto, afectando también la pared medial de la órbita. El enfoque aplicado fue la osteosíntesis de fracturas y la reconstrucción del dorso nasal. Los rastros de fractura se expusieron del abordaje coronal, se redujeron las fracturas y se usaron injertos de casquete para reconstruir el dorso nasal. La fractura y el injerto se fijaron con placas de sistema de 1,6 mm y se realizó la cantopexia de los ligamentos cantales mediales. Se requirió cirugía reparadora secundaria para la corrección de la pared lateral de la nariz, que persistió en el postoperatorio. Actualmente el paciente se encuentra en un estado de conservación y período de seguimiento de 665 días. En casos de fracturas nasoorbitales-etmoidales complejas, el diagnóstico y el tratamiento tempranos son esenciales para minimizar las secuelas y proporcionar un mejor resultado estético y funcional.

PALABRAS CLAVE: fijación de fracturas internas, reducción abierta, huesos faciales, lesiones faciales.

\section{REFERENCES}

Ellis 3rd, E. Sequencing treatment for naso-orbito-ethmoid fractures. J. Oral Maxillofac. Surg., 51(5):543-58, 1993.

Herford, A. S.; Ying, T. \& Brown, B. Outcomes of severely comminuted (type III) nasoorbitoethmoid fractures. J. Oral Maxillofac. Surg., 63(1):1266-77, 2005.

Liau, J. Y.; Woodlief, J. \& van Aalst, J. A. Pediatric nasoorbitoethmoid fractures. J. Craniofac. Surg., 22(5):1834-8, 2011.

Markowitz, B. L.; Manson, P. N.; Sargent, L.; Vander Kolk, C. A.; Yaremchuk, M.; Glassman, D. \& Crawley, W. A. Management of the medial canthal tendon in nasoethmoid orbital fractures: the importance of the central fragment in classification and treatment, Plast. Reconstr. Surg., 87(5):843-53, 1991.

Maves, M. D. \& Matt, B. H. Calvarial bone grafting of facial defects. Otolaryngol. Head Neck Surg., 95(4):464-70, 1986.

Melo, M. F. S.; Zanettini, L. M. S.; Lukschal, L. F.; Silveira, R. L. \& Amaral, M. B. F. Correção de fratura fronto-naso-órbito-etmoidal: passos cirúrgicos para resultado estético. Ver. Cir. Traumatol. Buco-Maxilo-Fac., 15(1):33-40, 2015.

Silva, H. C. L.; Gaetti Jardim, E. C.; Gonçalves, J. B. O.; Faverani, L. P.; Okamoto, R. \& Mendonça, J. C. G. Fraturas naso-orbitoetmoidal: diagnóstico e tratamento. Arch. Health Invest., 3(6):4654, 2014.

Soares, L. P.; Gaião, L.; Santos, M. E. S. M.; Pozza, A. H. \& de Oliveira, M. G. Indicações da tomografia computadorizada no diagnóstico das fraturas naso-órbito-etmoidais. Rev. Clín. Pesq. Odontol., 1(1):1-6, 2004.

Corresponding author:

Lucas Cavalieri Pereira

Departament of Oral and Maxillofacial Surgery

Hospital dos Fornecedores de Cana de Piracicaba

BRAZIL

Email: dr.lucasmaxilofacial@hotmail.com

Received: 26-09-2019

Accepted: 27-12-2019 